Volume: 12 Issue: 1 Year: 2015

\title{
The short version of service-learning involvement scale: The study of linguistic equivalence, validity and reliability
}

\author{
Adnan Küçükoğlu' \\ Ceyhun Ozan ${ }^{2}$
}

\begin{abstract}
The aim of the study is to adapt "Short Version of Scale of Service Learning Involvement" (SSLI), developed by Olney and Grande in 1995, into Turkish and report the validity and reliability studies. Pre-service teachers $(n=313)$ enrolled to a community service learning course in a public university in Turkey, and completed SSLI. Results of language equivalency showed that the correlation coefficients between Turkish and English forms ranged between .41 to .86. Results of exploratory factor analysis showed that the scale which was reduced to 30 items from 64 items and the 30 items loaded on three factors. The total variance explained was $43.3 \%$ and factor loadings ranged between .33 to .65. Confirmatory factor analyses indicated that a three factors structure of the SV-SSLI provided a good fit to the observed data. The internal consistency reliability coefficient of the scale was found as .85 and the test-retest reliability coefficient was found as .81. Based upon the results of the validity and reliability studies, it was determined that the adapted Turkish form of the inventory is a valid and reliable instrument that can be used to determine the social responsibility levels of pre-service teachers and their views about the community service learning in teacher training curriculum and their social responsibility levels through service-learning.
\end{abstract}

Keywords: Community service learning course, service learning, social responsibility, scale adaptation.

\section{Introduction}

Social responsibility is defined as "a sense of the obligations of citizenship, awareness of social injustice and its complex causes, and dedication to working toward social equity" (Olney \& Grande, 1995, p.43). The same authors described the development of social responsibility in three phases. The first phase is exploration, in which students participate in volunteer work mainly for fun or to be part of a peer group; the second phase is realization, in which students begin to commit to an

\footnotetext{
1 Assoc. Prof., Atatürk University, Kazım Karabekir Education Faculty, Department of Educational Sciences, adnank@atauni.edu.tr

2 Res. Assist., Atatürk University, Kazım Karabekir Education Faculty, Department of Educational Sciences, ozanceyhun@atauni.edu.tr
} 
Küçükoğlu, A., \& Ozan, C. (2015). The short version of service-learning involvement scale: The study of linguistic equivalence, validity and reliability. International Journal of Human Sciences, 12(1), 790-810. doi: $\underline{10.14687 / \text { ijhs.v12i1.2852 }}$

issue, site, or activity; and the third phase is internalization, where students are aware of the complexities and importance of social justice issues and are committed to work toward social equality and equity.

An increasing number of institutions and corporations have been working on fulfilling their responsibilities to the society they live in. Among these are the educational institutions. Both the primary and the secondary and also the higher education institutions carry out their social responsibilities by raising and educating students as individuals who are sensitive to their environment and society. The concept 'service-learning' in the literature indicates the responsibilities of the citizens to the society in which they live in democratic societies (Sliwka, 2004, quoted by Saran, Coşkun, İnal-Zorel \& Aksoy, 2011).

The young getting educated in universities find the opportunity to develop their skills to serve individually for the society via service-learning as a learning method besides acquiring a profession during and after their education. Therefore today, the universities aim to educate students in order to seek the meaning of life (Hoffinger, 2009, quoted by Saran et al., 2011). Supporting university students' professions with participation in the works on behalf of society provides the implementation dimension of education to be understood better by the students and also raises students' awareness about the individual responsibilities towards the society by participating actively in these works (Saran et al., 2011). According to Astin (1999), if the universities want students to have the basic values of democracy such as honesty, tolerance, empathy, generosity, team work, cooperation, service and social responsibility, they should give place to these values in their programs and policies besides bringing students in these values, which can be done best with service-learning.

Service-learning has been applied in education institutions from different countries around the world for a long time, and attending this program has been considered to be a substantial criterion to graduate from the education institution and to be accepted to the higher education. Considering the universities abroad, it is seen that institutes, departments and master/postgraduate degrees have programs about social responsibility (Saran et al, 2011). In Turkey in 2005, correspondingly to the update of primary and secondary schools' programs by Ministry of National Education, Council of Higher Education (CHE) also updated the education programs of faculties of education in universities and put the community service learning course into effect in 2006. After the implementation of this course by CHE, some universities made this course compulsory in all of their faculties according to the decision made by them and some other universities made it 
Küçükoğlu, A., \& Ozan, C. (2015). The short version of service-learning involvement scale: The study of linguistic equivalence, validity and reliability. International Journal of Human Sciences, 12(1), 790-810. doi: $\underline{10.14687 / \text { ijhs.v12i1.2852 }}$

compulsory in some of their faculties. The community service learning course has the feature of gaining consciousness of social responsibility theoretically and practically and intending to develop cooperation, solidarity, effective communication and self-assessment skills during the practice. The community service learning course is a 1-hour theoretic and 2-hour practical course, that is, it is a 3hour and 2-credit course in a week.

In this sense, researches on community service learning course and service-learning have been started to be done increasingly since 2006 in Turkey (Ayvacı \& Akyıldız, 2009; Dinçer, Ergül, Şen, \& Çabuk, 2011; Elma, Kesten, Kıroğlu, Mercan Uzun, Dicle \& Palavan, 2010; Gökçe, 2011; Horzum and Bektaş, 2012; Kesten, Elma, Kıroğlu, Dicle, Mercan Uzun \& Palavan, 2011; Küçükoğlu, 2011; Küçükoğlu, Kaya \& Bay, 2010; Küçükoğlu, Kaya, Bay, Taşgin \& Ozan, 2010; Küçükoğlu, Ozan \& Taşgin, 2012, Özdemir \& Tokcan, 2010; Saran et al., 2011; Sönmez, 2010; Uğurlu \& Kıral, 2011; Ural-Keleş \& Aydın, 2011; Yılmaz, 2011).

Delve, Mintz, and Stewart (1990) developed a Scale of Service-Learning Involvement (SSLI) that draws on the cognitive and moral development theories of Perry, Kohlberg, and Gilligan. The scale outlines five phases of social responsibility as students engage in service-learning experiences: Exploration, clarification, realization, activation, and internalization. In the exploration phase, students are eager to help and become involved, but have no focused commitment. The next phase, clarification, is also exploratory, but students begin to clarify their values regarding service work. During the third phase, realization, students begin to connect service work to their lives, and show an increased excitement and commitment to their service site. The activation phase finds students beginning to grasp a larger, more complex understanding of social issues, and they often become motivated by the injustices they observe: they become advocates. During the fifth and final phase, internalization, students integrate the service experience into their lives, often into their personal or career goals (Olney \& Grande, 1995). This stage model is useful not only to better estimate where students are developmentally so educators can better challenge and support them, but it also begins to articulate a useful research tool to measure outcomes of service-learning.

Olney and Grande report on the psychometric qualities of the "Scale of Service Learning Involvement" (SSLI) developed to measure the effects of service-learning on the evolution of college student's sense of social responsibility. The SSLI was based on a model by Delve, Mintz, and Stewart (1990), which provides a model for assessing the developmental effects of servicelearning on students as they move through a process of exploration, clarification, realization, activation, and internalization. The authors claim the SSLI instrument serves as a useful tool while 
Küçükoğlu, A., \& Ozan, C. (2015). The short version of service-learning involvement scale: The study of linguistic equivalence, validity and reliability. International Journal of Human Sciences, 12(1), 790-810. doi: $\underline{10.14687 / \text { ijhs.v12i1.2852 }}$

assessing the impact of service-learning programs on student development. They suggest utilizing the SSLI would assist practitioners' enhancing their program by identifying where students are situated on the continuum of development.

However, it was seen upon looking through the literature that there are a limited number of developed or adapted scales about service-learning (Elma et al., 2010; Horzum \& Bektaş, 2012; Özdemir \& Tokcan, 2010). On the other hand, it was concluded that in Turkey, there is not any scales about community service learning course and service-learning in the context of social responsibility. In this respect, it was considered to be important to do the study of reliability, validity and adaptation of "Scale of Service Learning Involvement" (SSLI) which was developed by Olney and Grande (1995) to determine the views of pre-service teachers about service-learning in the context of social responsibility into Turkish to fill a gap in the literature. The aim of the study is to adapt "Short Version of Scale of Service Learning Involvement" (SV-SSLI), developed by Olney and Grande in 1995, to Turkish and does the validity and reliability studies.

\section{Method}

\section{Study Groups}

In the research, three different study groups were included to make the linguistic equivalence, validity and reliability studies of the scale. All of these three study groups were formed of preservice teachers who were voluntary to participate in and get educated in faculty of education in public university in the spring semester of 2011-2012 education years. As the scale includes items about "Community Service Learning Course", the study groups were carefully formed of preservice teachers who have taken this course. In this context, the study groups were formed of preservice teachers who got educated in spring semester of 2011-2012 education years and took "Community Service Learning Course". The first study group was formed of 50 pre-service students, who got formal education in the Department of Education English Language and took assessment and evaluation course, to do the linguistic equivalence study of the scale. 313 pre-service teachers from various departments took part in the second study group formed to determine the construct validity of the scale. The demographic information about the second study group is indicated in Table 1. 50 pre-service teachers who got formal education in the Department of Elementary Social Sciences Education took part in the third study group whose reliability was determined with test-retest method. 
Küçükoğlu, A., \& Ozan, C. (2015). The short version of service-learning involvement scale: The study of linguistic equivalence, validity and reliability. International Journal of Human Sciences, 12(1), 790-810. doi: $10.14687 /$ ijhs.v12i1.2852

Table 1. Data about the Second Study Group

\begin{tabular}{lll}
\hline & $\mathbf{f}$ & $\mathbf{\%}$ \\
\cline { 2 - 3 } Sex & 182 & 58.1 \\
Female & 131 & 41.9 \\
Male & & \\
Program & 100 & 31.9 \\
Turkish Education & 107 & 24.2 \\
Social Sciences Education & & \\
Guidance and Psychological & 67 & 21.5 \\
Counseling & & \\
English Language Education & 39 & 12.5 \\
Total & $\mathbf{3 1 3}$ & $\mathbf{1 0 0}$ \\
\hline
\end{tabular}

\section{Measurement Instrument}

The "Scale of Service Learning Involvement" (SSLI) developed by Olney and Grande (1995) to determine the views of pre-service teachers about service-learning were used after the necessary permissions were granted by the developers by contacting with them via e-mail. The original form of the scale consists of 21 items of exploration, 21 items of realization and 22 items of internalization, which means it consists of three factors and 64 items. This study does not include all of these 64 items and it was thought it would be better to make the scale shorter to be a more practical scale. With this purpose, items which are present in American education system but not in Turkish education system and expressions which are for measuring similar features were subtracted from the scale in line with the views of researchers. In this context, 34 items were subtracted from the scale by considering not spoiling the three factor structure of the original scale. 30 items, 10 items for each of these three factors, take part in the new short version of the scale. Olney and Grande (1995) who developed the scale stated in the suggestion part of their study that it would be affirmative to shorten the 64 item-structure of the scale. $6^{\text {th }}, 9^{\text {th }}, 13^{\text {th }}, 21^{\text {st }}, 22^{\text {nd }}, 25^{\text {th }}$ and $27^{\text {th }}$ items consist of negative expressions in the short version of the scale consisting of 30 items. The scale is ranked as "strongly disagree (1)", "disagree (2)", "agree (3)" and "strongly agree (4)" as in 4 point Likert scale. The higher the points gathered after reversing the negative items are, the more positive the views of pre-service teachers about service-learning are. Cronbach alpha internal consistency coefficient related to the original form of the scale determined as .84 for exploration dimension, .70 
Küçükoğlu, A., \& Ozan, C. (2015). The short version of service-learning involvement scale: The study of linguistic equivalence, validity and reliability. International Journal of Human Sciences, 12(1), 790-810. doi: $\underline{10.14687 / \text { ijhs.v12i1.2852 }}$

for realization dimension and .74 for internalization dimension. The final scale is presented in the Appendix 1.

\section{Process}

In the first stage, the linguistic equivalence studies of the scale were done. First, the English form of the scale was translated into Turkish by the researcher, then, it was analyzed by three academicians who are masters in the field and both languages, and necessary corrections were made. Thereafter, the Turkish form of the scale was analyzed in terms of meaning and grammar, necessary corrections were done and then the Turkish form of the scale was obtained to be tried. The Turkish and English forms of the scale was applied on $503^{\text {rd }}$ grade pre-service teachers from department of Education English Language every other three weeks and the results between the two forms of the scale were calculated with Pearson Product-Moment Correlation Coefficient. The construct validity of the scale was analyzed with exploratory factor analysis (EFA) and confirmatory factor analysis (CFA). Exploratory factor analysis aims to discover the factor structure based on the relations between the variables. Hypothesis about the relations between the variables is tested in the confirmatory factor analysis which aims to analyze model-data harmony (Kline, 2000; Tabachnick \& Fidell, 2007). Chi Square Fit Test, Root-Mean-Square Error (RMSEA), Standardized Root Mean Residual (SRMR), Normed Fit Index (NFI), Non-Normed Fit Index (NNFI), Comparative Fit Index (CFI), Goodness of Fit Index (GFI) and Adjusted Goodness of Fit Index (AGFI) were used to evaluate the validity of the model formed in CFA. Item-total correlations were calculated in order to determine how adequate each item in the scale was to discriminate the pre-service teachers in terms of their views about service-learning. T-test for independent groups was used for the significance of the differentiation between item-points of the $27 \%$ subgroup and the $27 \%$ upper group according to total points. Cronbach Alpha internal consistency coefficient and correlation coefficient obtained with test-retest method were calculated to determine the reliability of the scale. SPSS 20.0 and Lisrel 8.80 were used for statistical analysis.

\section{Findings}

Translation of a scale is a substantive problem in the adaptation studies of a scale from a different culture and having psychological features into another culture and it is required the items in the translated scale to adequately represent the items in the original form of the scale (Deniz, 2007). Because of this reason, the linguistic equivalence studies of the scale was carried on and first applied on the $4^{\text {th }}$ grade 50 students from department of education English education every three weeks because they know English and they have taken "Community Service Learning Course". The time 
Küçükoğlu, A., \& Ozan, C. (2015). The short version of service-learning involvement scale: The study of linguistic equivalence, validity and reliability. International Journal of Human Sciences, 12(1), 790-810. doi: $10.14687 /$ ijhs.v12i1.2852

span of the two tests should not be less than two weeks and more than four weeks (McLaughlin and Marasculio, 1990; quoted by: Gözüm \& Aksayan, 2003; Özgüven, 2000). In the linguistic equivalence study of the scale, first it was analyzed that whether the obtained data fits the normal distribution or not. Kolmogorov-Smirnov Test was applied for the relevancy of normal distribution and as a result it was determined that the normality hypothesis was granted for both the English form $(\mathrm{Z}=.87 ; \mathrm{p}>.05)$ and the Turkish form $(\mathrm{Z}=.72 ; \mathrm{p}>.05)$. Pearson Product-Moment Correlation Coefficient test was applied to determine the correlation coefficients at the level of items between the English and Turkish forms. Pearson Product-Moment Correlation Coefficients are supposed to be significance.

The significance values and correlation coefficients obtained from the items related to the scale and the English and Turkish forms of the scale applied on the same group are indicated in Table 2.

Table 2. The significance values and correlation coefficients related to the English and Turkish forms of the scale

\begin{tabular}{llllll}
\hline $\begin{array}{l}\text { Item } \\
\text { No }\end{array}$ & $\mathbf{r}$ & $\mathrm{p}$ & $\begin{array}{l}\text { Item } \\
\text { No }\end{array}$ & $\mathrm{r}$ & $\mathrm{p}$ \\
\hline 1 & .86 & $\mathrm{p}<.01$ & 16 & .50 & $\mathrm{p}<.01$ \\
2 & .71 & $\mathrm{p}<.01$ & 17 & .80 & $\mathrm{p}<.01$ \\
3 & .56 & $\mathrm{p}<.01$ & 18 & .59 & $\mathrm{p}<.01$ \\
4 & .49 & $\mathrm{p}<.01$ & 19 & .82 & $\mathrm{p}<.01$ \\
5 & .41 & $\mathrm{p}<.01$ & 20 & .68 & $\mathrm{p}<.01$ \\
6 & .52 & $\mathrm{p}<.01$ & 21 & .57 & $\mathrm{p}<.01$ \\
7 & .49 & $\mathrm{p}<.01$ & 22 & .55 & $\mathrm{p}<.01$ \\
8 & .54 & $\mathrm{p}<.01$ & 23 & .83 & $\mathrm{p}<.01$ \\
9 & .82 & $\mathrm{p}<.01$ & 24 & .44 & $\mathrm{p}<.01$ \\
10 & .47 & $\mathrm{p}<.01$ & 25 & .64 & $\mathrm{p}<.01$ \\
11 & .61 & $\mathrm{p}<.01$ & 26 & .85 & $\mathrm{p}<.01$ \\
12 & .53 & $\mathrm{p}<.01$ & 27 & .56 & $\mathrm{p}<.01$ \\
13 & .46 & $\mathrm{p}<.01$ & 28 & .51 & $\mathrm{p}<.01$ \\
14 & .47 & $\mathrm{p}<.01$ & 29 & .77 & $\mathrm{p}<.01$ \\
15 & .64 & $\mathrm{p}<.01$ & 30 & .64 & $\mathrm{p}<.01$ \\
\hline
\end{tabular}

According to the table, it can be seen that all of the items in the scale are significance at the level of $\mathrm{p}<.01$ and have a positive correlation. The correlation values between the items change between .41 
Küçükoğlu, A., \& Ozan, C. (2015). The short version of service-learning involvement scale: The study of linguistic equivalence, validity and reliability. International Journal of Human Sciences, 12(1), 790-810. doi: $\underline{10.14687 / \text { ijhs.v12i1.2852 }}$

and .86. Hereunder, it was accepted that the linguistic equivalence of both the English and Turkish forms was provided for all of the items in the scale.

\section{Exploratory Factor Analysis (EFA)}

In the study, exploratory factor analysis (EFA) was used to reveal the effect of "Short Version of the Scale of Service Learning Involvement" on Turkish students. EFA aims to determine limited number of significance structures from a great number of variables (items) with which the significance structures can be defined. The key criterion in evaluation of factor analysis results is the factor loads which can be thought as the correlation between variables and factors. Higher factor loadings are considered to be an indicator that the variable can be under the mentioned factor (Büyüköztürk, 2010). It is preferred that the value of item factor load should be 0.45 or higher. However, it can be seen that the value of factor load is accepted to be until 0.30 for less items in the studies (Büyüköztürk, 2010; Hair, Black, Babin \& Anderson, 2010; Kline, 2000; Tabachnick \& Fidell, 2007). In this study, .30 was taken as a criterion key to find factor loads adequate. In EFA, first it was analyzed that whether there was a considerable amount of significance correlations by analyzing the matrix between all of the items and it was seen that there were significance relationships which qualified to make factor analysis. Then, Kaiser-Meyer-Olkin (KMO) and Barlett Sphericity tests were done for sampling adequacy. KMO results should be higher than .60 and Barlet test results should be significance for the qualification of data for factor analysis (Kaiser, 1974; Pallant, 2005). If the KMO value is closer to 1, it can be said that the relationships between the variables are clear and the factor analysis will give reliable results (Field, 2009). In this study, KMO coefficient of Sampling Adequacy was found as .86, $\chi^{2}$ value of Bartlett Sphericity test was found as $2164,010(\mathrm{p}<.001)$. These values show that the data is convenient for the factor analysis.

As the original form of "Scale of Service-Learning Involvement" includes three factors, the result of direct oblimin rotation and principal component factor analysis were limited to three factors. If there is orthogonality between the factors of a scale, varimax rotation method is used; if there is a constant relation sequence, oblimin rotation method is used (Gorsuch, 1974; Tabachnick \& Fidell, 2007). In this study, oblimin rotation method was used because there were relations between the factors of the scale. As a result of the conducted analysis, a 3-factor structure which explains the $43.339 \%$ of total variance and whose items take part in the sub-dimensions of the original form was appeared. Moreover, it was not required to subtract any item form the scale as the factor loads of all items were higher than .30 . The data related to the factor structure of the shortened Turkish form is indicated in Table 3. 
Küçükoğlu, A., \& Ozan, C. (2015). The short version of service-learning involvement scale: The study of linguistic equivalence, validity and reliability. International Journal of Human Sciences, 12(1), 790-810. doi: $10.14687 /$ ijhs.v12i1.2852

Table 3. Dimensions of Scale and Item Factor Loadings

\begin{tabular}{|c|c|c|c|}
\hline Item Number & Exploration & Realization & Internalization \\
\hline 22 & .569 & & \\
\hline 7 & .544 & & \\
\hline 10 & .538 & & \\
\hline 16 & .532 & & \\
\hline 17 & .482 & & \\
\hline 2 & .451 & & \\
\hline 29 & .422 & & \\
\hline 11 & .411 & & \\
\hline 1 & .403 & & \\
\hline 4 & .376 & & \\
\hline 8 & & .653 & \\
\hline 23 & & .610 & \\
\hline 19 & & .605 & \\
\hline 3 & & .527 & \\
\hline 15 & & .464 & \\
\hline 13 & & .420 & \\
\hline 9 & & .388 & \\
\hline 6 & & .371 & \\
\hline 27 & & .348 & \\
\hline 30 & & .329 & \\
\hline 26 & & & .593 \\
\hline 20 & & & .591 \\
\hline 24 & & & .543 \\
\hline 21 & & & .507 \\
\hline 12 & & & .500 \\
\hline 5 & & & .490 \\
\hline 28 & & & .489 \\
\hline 14 & & & .446 \\
\hline 25 & & & .419 \\
\hline 18 & & & .424 \\
\hline \multicolumn{4}{|l|}{ Explained } \\
\hline $\begin{array}{l}\text { Total }= \\
43.339\end{array}$ & $\% 21.921$ & $\%$ & $\% 9.913$ \\
\hline
\end{tabular}


Küçükoğlu, A., \& Ozan, C. (2015). The short version of service-learning involvement scale: The study of linguistic equivalence, validity and reliability. International Journal of Human Sciences, 12(1), 790-810. doi: $\underline{10.14687 / \text { ijhs.v12i1.2852 }}$

As it can be seen in Table 3, the Turkish form of the Scale of Service Learning Involvement consists of three factors as the original form does and these three factors explain $43.339 \%$ of the total variance. The first dimension is named as "Exploration" and consists of 10 items. Exploration dimension explains 21.921 of total variance and its factor loads change between .38 and .57 . The second dimension, named as "Realization" and consisting of 10 items, explains $11.445 \%$ of total variance and the factor loadings of the items change between .33 and .65 . The last and the third dimension named as "Internalization" also consists of 10 items and it explains $9.973 \%$ of total variance. The factor loadings of the items in this dimension change between .42 and .60 . Besides the factor loadings and the variance proportions they explain, the correlations between the dimensions were also analyzed. The correlation coefficients related to dimensions are indicated in Table 4.

Table 4. Correlation Between Dimensions

\begin{tabular}{llll}
\hline Dimension & Exploration & Realization & Internalization \\
\hline Exploration & & & \\
Realization & $.785^{*}$ & & \\
Internalization & $.810^{*}$ & $.687^{*}$ & \\
Total & $.896^{*}$ & $.855^{*}$ & $.884^{*}$ \\
\hline${ }^{*}<0.01$ & &
\end{tabular}

As it seen in Table 4, the correlations between the total points obtained from the scale and the points of sub-factors change between 0,79 and 0,90 and these correlation coefficients are found to be significance at a level of 0,01 . The higher and significance correlations indicate that these three factors are the sub-factors of the Scale of Service-Learning Involvement.

\section{Confirmatory Factor Analysis (CFA)}

CFA is a validity determination method used in the adaptation of measurement instruments which are developed especially in other cultures and samples. According to Sümer (2000), CFA is an analysis to evaluate how the factors constituted of several variables accord with the real data by taking support from a hypothetic basis. In other words, CFA aims to investigate a predetermined or built structure to what extend they are confirmed with the obtained data. EFA is based on the prove of specific variables which will predominantly take part in predetermined variables under the basis of a hypothesis while the factor structure of data is determined without a pre-expectation or hypothesis on a basis of factor loads in confirmatory factor analysis. 
Küçükoğlu, A., \& Ozan, C. (2015). The short version of service-learning involvement scale: The study of linguistic equivalence, validity and reliability. International Journal of Human Sciences, 12(1), 790-810. doi: $\underline{10.14687 / \text { ijhs.v12i1.2852 }}$

Several fit indexes are used to determine the fitness adequacy of the model tested in CFA. Because fit indexes have strengths and weaknesses in evaluating fitness between the hypothetic model and real data compared to each other, it is suggested to use several fit index values to present the fitness of the model (Büyüköztürk, Akgün, Özkahveci \& Demirel, 2004). The most frequently used fit indexes are Chi-Square Goodness, Root Mean Square Error of Approximation (RMSEA), Standardized Root Mean Square Residual (SRMR), Normed Fit Index (NFI), Non-normed Fit Index (NNFI), Comparative Fit Index (CFI), Goodness of Fit Index (GFI) and Adjusted Goodness of Fit Index (AGFI). While the calculated Chi-Square/df value between 0 and 2, RMSEA value between 0.01 and 1, SRMR value between 0 and 0.05 , NFI and GFI values between 0.95 and 1, NNFI and CFI values between 0.97 and 1 and AGFI value between 0.90 and 1 mean that the model shows a very well fitness, the Chi-Square/sd value between 2 and 3, RMSEA value between 0.05 and 0.08 , SRMR value between 0.05 and 0.10 , NFI and GFI values between 0.90 and 0.95, NNFI and CFI values between 0.95 and 0.97 and AGFI value between 0.85 and 0.90 mean that the model is in an acceptable fitness (Baumgartner \& Hombur, 1996; Byrne \& Campbell, 1999; Gefen \& Straub, 2000; Hooper, Coughlan \& Mullen, 2008; Hu \& Bentler, 1999). The fit indexes of the model obtained from the applied CFA were analyzed and it was seen that the statistics are up to the mark. The obtained values are indicated in the Table 5 .

Table 5. The Values Related to the Goodness of Fit Indexes of the Scale

\begin{tabular}{lllllllllll}
\hline $\begin{array}{l}\text { Chi- } \\
\text { Square }\end{array}$ & df & $\mathrm{p}$ & $\begin{array}{l}\text { Chi- } \\
\text { Square } \\
/ \mathrm{df}\end{array}$ & RMSEA & SRMR & NFI & NNFI & CFI & GFI & AGFI \\
\hline 840.84 & 402 & $\mathrm{p}<0.05$ & 2.09 & 0.059 & 0.085 & 0.93 & 0.98 & 0.98 & 0.93 & 0.88 \\
\hline
\end{tabular}

Upon analyzing the Table 5, it can be seen that the chi-square value is significance and the proportion of chi-square value to the degree of freedom is between an acceptable range of 2 and 3 . On analyzing the values related to other fit indexes, it can be said that they all are in between acceptable ranges and according to these acquired results, fitness of model and data was provided and the structure validity of the scale was confirmed. The diagram regarding the applied confirmatory factor analysis is indicated in Figure 1. 
Küçükoğlu, A., \& Ozan, C. (2015). The short version of service-learning involvement scale: The study of linguistic equivalence, validity and reliability. International Journal of Human Sciences, 12(1), 790-810. doi: $10.14687 /$ ijhs.v12i1.2852

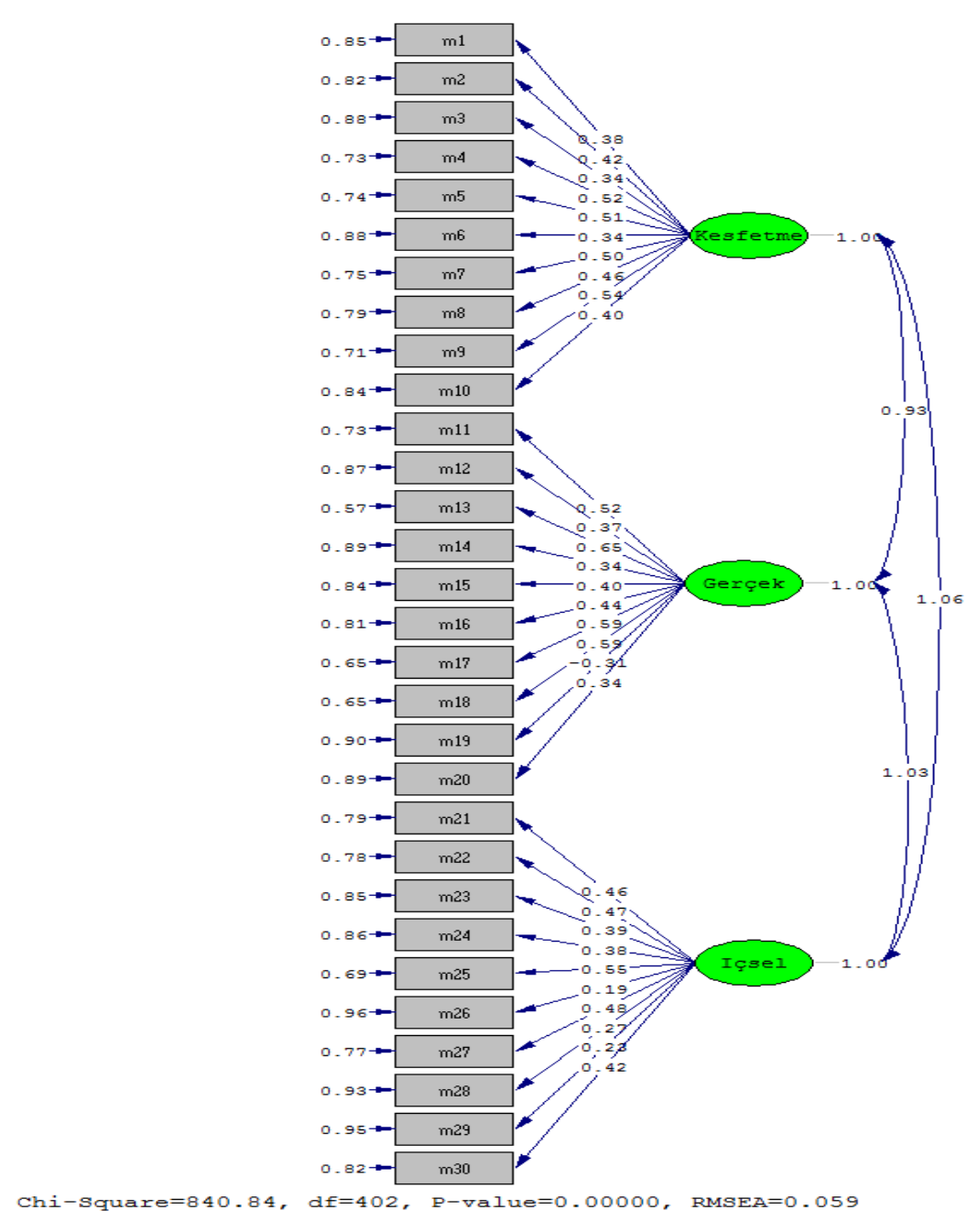

Figure 1. Diagram about the Confirmatory Factor Analysis

The correlation coefficients and the amount of the effect of each item on latent dependent variables are seen in Figure 1. It is seen that the correlation coefficients regarding the items change between .19 and .65. According to these gathered data, it came to a fruition that the 3-factor and 30-item structure of the Short Version of the Scale of Service-Learning Involvement is theoretically and hypothetically a valid scale theoretically and hypothetically.

\section{Reliability}

The reliability studies of the scale were conducted with two different method, internal consistency and stability. Cronbach alpha internal consistency coefficient was used to determine the consistency of the scale and test-retest was used to determine the stability of the scale. Test-retest method was 
Küçükoğlu, A., \& Ozan, C. (2015). The short version of service-learning involvement scale: The study of linguistic equivalence, validity and reliability. International Journal of Human Sciences, 12(1), 790-810. doi: $\underline{10.14687 / \text { ijhs.v12i1.2852 }}$

applied on 50 pre-service teachers who did not take part in the construct validity studies of the scale two times every three weeks. Data about the internal consistency of the scale is indicated in Table 6.

Table 6. Data about the Internal Consistency of the Scale

\begin{tabular}{lll}
\hline Factor & $\begin{array}{l}\text { Number of } \\
\text { Items }\end{array}$ & $\begin{array}{l}\text { Cronbach Alfa } \\
\text { Coefficients }\end{array}$ \\
\hline Exploration & 10 & .81 \\
Realization & 10 & .72 \\
Internalizatio & 10 & .75 \\
$\mathrm{n}$ & & .85 \\
Total & 30 & \\
\hline
\end{tabular}

According to Cronbach (1951), if the internal consistency coefficient were between .7 and .8, it would be acceptable; if it were between .8 and .9 it would be good; and if it were between .9 and 1 , it would be perfect. That the total value of the internal consistency is higher than .72 shows that the scale is consistent and it means that the scale produces consistent data. The data obtained from test-retest method was compared to Pearson product-moment correlation. Data about the correlation analysis is indicated in Table 7.

Table 7. Data about Test-Retest Method of Scale

\begin{tabular}{lllll}
\hline Dimension & Application & $\mathrm{M}$ & $\mathrm{sd}$ & $\mathrm{r}$ \\
\hline \multirow{2}{*}{ Exploration } & First application & 30.39 & 4.02 & \multirow{2}{*}{.86 } \\
& Second application & 31.02 & 4.38 & \\
\multirow{3}{*}{ Realization } & First application & 28.18 & 3.91 & \multirow{2}{*}{ Internalization } \\
& Second application & 29.08 & 4.61 & \\
& First application & 29.26 & 3.84 & \multirow{2}{*}{ Total } \\
& Second application & 29.83 & 3.93 & \\
& First application & 87.83 & 10.34 & \multirow{2}{*}{.81} \\
& Second application & 88.90 & 10.71 & \\
\hline
\end{tabular}

When analyzing the evidence obtained from the test-retest study of the scale, it is seen that correlation coefficients for the three sub-dimensions of the scale are $.86, .80$ and .84 , respectively, and .81 within the scale. Tavşancil (2002) stated that the correlation value calculated by test-retest method should be at least 0.70 to be accepted as high. Accordingly, it can be said that the reliability coefficients of the scale and the dimensions calculated with test-retest method are high and so the scale produces stable results. 
Küçükoğlu, A., \& Ozan, C. (2015). The short version of service-learning involvement scale: The study of linguistic equivalence, validity and reliability. International Journal of Human Sciences, 12(1), 790-810. doi: $\underline{10.14687 / \text { ijhs.v12i1.2852 }}$

\section{Item Discrimination}

First of all, item total correlation values of the scale was calculated to determine how adequate each item in the scale is to discriminate the pre-service teachers in terms of their attitudes towards assessment and evaluation in education. Secondly, t-test was used for the significance of the difference between item points of $27 \%$ sub-group and $27 \%$ upper-group compared to the total points. The results are indicated in Table 8.

Table 8. T-Test for Item Total Correlation and Item Discrimination

\begin{tabular}{|c|c|c|c|c|c|}
\hline Items & $\begin{array}{l}\text { Adjusted } \\
\text { Item-Total } \\
\text { Correlations }\end{array}$ & $\mathrm{t}$ & Items & $\begin{array}{l}\text { Adjusted } \\
\text { Item-Total } \\
\text { Correlation }\end{array}$ & $\mathrm{t}$ \\
\hline i1 & .355 & $6.255^{*}$ & i16 & .447 & 7.624* \\
\hline i2 & .408 & $7.720^{*}$ & i17 & .429 & $8.337^{*}$ \\
\hline i3 & .442 & $8.174^{*}$ & i18 & .369 & $5.903^{*}$ \\
\hline i4 & .331 & $5.514^{*}$ & i19 & .524 & $10.129 *$ \\
\hline i5 & .415 & $7.245^{*}$ & $i 20$ & .384 & $10.204^{*}$ \\
\hline i6 & .310 & $6.375^{*}$ & i21 & .519 & $4.892 *$ \\
\hline i7 & .471 & 9.619* & ¡22 & .491 & $8.216^{*}$ \\
\hline i8 & .576 & $10.827 *$ & i23 & .527 & $9.198^{*}$ \\
\hline i9 & .352 & $7.345^{*}$ & i24 & .313 & $8.721 *$ \\
\hline i10 & .480 & $7.398^{*}$ & i25 & .474 & $5.182^{*}$ \\
\hline i11 & .326 & $5.933^{*}$ & i26 & .349 & $4.653^{*}$ \\
\hline i12 & .454 & $7.633^{*}$ & i27 & .357 & $4.963^{*}$ \\
\hline i13 & .350 & $6.055^{*}$ & i28 & .408 & $7.763^{*}$ \\
\hline i14 & .382 & $5.876^{*}$ & i29 & .369 & $5.802^{*}$ \\
\hline i15 & .383 & $8.297 *$ & $i 30$ & .381 & $4.434 *$ \\
\hline
\end{tabular}

According to obtained evidence, it was seen that the reorganized item-total correlations ranged between .33 and $.66, \mathrm{t}(\mathrm{sd}=168)$ values related to the differences, which were determined according to total points, between the item points of $27 \%$ sub-group and $27 \%$ upper-group ranged between $4.43(\mathrm{p}<.001)$ and $10.83(\mathrm{p}<.001) .30$ is considered to be as an acceptable lower limit for item-total correlations (Nunnaly \& Bernstein, 1994). The results of t-test showed that the item-total point of $27 \%$ upper-group is significance $(\mathrm{p}<0.001$ ) higher than the same point of $27 \%$ sub-group through all items. 
Küçükoğlu, A., \& Ozan, C. (2015). The short version of service-learning involvement scale: The study of linguistic equivalence, validity and reliability. International Journal of Human Sciences, 12(1), 790-810. doi: $\underline{10.14687 / \text { ijhs.v12i1.2852 }}$

There are 30 items gathered in three factors in the Turkish Short Version of the Scale of ServiceLearning Involvement. The highest point gotten from the scale which is a 4-point Likert-type scale and ranged from "1" (strongly disagree) to "4" (strongly agree) is 120 and the lowest point is 30 . Because the $6^{\text {th }}, 9^{\text {th }}, 13^{\text {td }}, 21^{\text {st }}, 25^{\text {th }}$ and $27^{\text {th }}$ items have negative expressions, reverse grading should be done. The higher points of each sub-dimensions of the scale show that the individual has positive views about the related sub-dimension. The total point which is gotten from the scale gives the general point of the individual about service-learning.

\section{Results and Discussion}

In this study, the linguistic equivalence, the reliability and the validity studies of Scale of Service Learning Investment (SSLI), which was developed by Olney and Grande (1995) to measure the social responsibility levels of pre-service students via service-learning, were applied on the preservice students in Turkey by creating a Short Version of the scale. Within this concept, first the relation between the Turkish and English form of the scale was calculated to clarify the linguistic equivalence of the Short Version of Scale of Service Learning Investment (SSLI) with the original form of the scale and high correlation was found both for the sub-dimensions and for the overall of the scale. This result shows that SV of SSLI has an adequate linguistic equivalence level with the original form of the scale and the translation process was completed successfully.

Exploratory factor analysis (EFA) and confirmatory factor analysis (CFA) was applied to examine the structure validity of the scale. A 3-factor structure, which explains the $43.3 \%$ of the total variance and includes all the 30 items completely presented in the short version just like they presented in the original form with all their sub-dimensions, was obtained according to the results obtained from the exploratory factor analysis (EFA). The factor loads of the scale items are found to be ranged between .33 and .57 . The firs dimension was called as "Exploration" and formed of 10 items, the second dimension was called as "Realization" and formed of 10 items and the third dimension was called as "Internalization" and formed of 10 items, as well. Dimension of "Interest" is about the usefulness and importance of assessment and evaluation for students and therefore it reflects the interests of the pre-service teachers about assessment and evaluation. The first dimension is exploration, in which students participate in volunteer work mainly for fun or to be part of a peer group; the second dimension is realization, in which students begin to commit to an issue, site, or activity; and the third dimension is internalization, where students are aware of the complexities and importance of social justice issues and are committed to work toward social 
Küçükoğlu, A., \& Ozan, C. (2015). The short version of service-learning involvement scale: The study of linguistic equivalence, validity and reliability. International Journal of Human Sciences, 12(1), 790-810. doi: $\underline{10.14687 / \text { ijhs.v12i1.2852 }}$

equality and equity. In another factor analysis, CFA, it was investigated that if the original factor structure of the scale was confirmed with this study carried out on the Turkish students or not. Considering the limits of fit indexes for CFA, it was determined that the model gives good fit and the original factor structure of the scale fits the Turkish Short Version of the scale.

Item analysis and comparison of $27 \%$ sub and upper groups were applied to present the item discrimination of SV of SSLI and the prediction degree of the total points of the items. The result of item analysis determined that the results about reorganized item-total correlation change between .31 and .58. It can be said that the consistency of item-total correlations about the scale is adequate in evaluating item-total correlation considering that the items with a value of .30 and higher are accepted (Büyüköztürk, 2010) to be adequate in discriminating the features to be measured. It was also seen that $\mathrm{t}$ values related to differences between $27 \%$ sub and upper groups change between $4.43(\mathrm{p}<.000)$ and 10,20 $(\mathrm{p}<000$.). These results showed that the item-total point of $27 \%$ upper-groups is significantly $(\mathrm{p}<0.001)$ higher than the same point of $27 \%$ sub-group for all the items.

According to results of reliability studies of SV of SSLI, Cronbach Alpha internal consistency coefficient was found as 0,85 , and for dimension as $0,81,0,72$ and 0,75 , respectively. However, the correlation coefficient obtained with test-retest method was calculated as 0,81 for the overall of the scale, and for the dimension as $0,86,0,80$ and 0,84 , respectively. The obtained evidence indicates that the measuring instrument is quite reliable.

Considering the results gathered via the validity and reliability studies, it was concluded that the scale which was reduced to 30 items from 64 items and adapted into Turkish is a reliable and valid tool to be used to determine social responsibility levels of pre-service teachers and their views about the community service learning in teacher training curriculum and their social responsibility levels through service-learning. It is thought that applying the scale on other pre-service-teacher groups in further studies of the scale contribute to the validity and reliability of the scale.

\section{References}

Astin, A. W. (1999). Promoting leadership, service, and democracy: What higher education can do. In R. G. Bringle, R. Games, and E. A. Malloy (Eds.), Colleges and universities as citizens (pp.3147). Needham Heights, MA: Allyn \& Bacon.

Ayvac1, H. S.., \& Akyıldız, S. (2009). Topluma hizmet uygulamaları dersinin bireye ve topluma kazandırdıkları ve toplumun beklentileri. Milli Ë̆itim, 38(184), 102-119.

Baumgartner, H., \& Hombur, C. (1996). Applications of structural equation modeling in marketing and consumer research: A review. International Journal of Research in Marketing, 13, 139-161. 
Küçükoğlu, A., \& Ozan, C. (2015). The short version of service-learning involvement scale: The study of linguistic equivalence, validity and reliability. International Journal of Human Sciences, 12(1), 790-810. doi: $10.14687 /$ ijhs.v12i1.2852

Büyüköztürk, Ş. (2010). Sosyal bilimler için veri analiz̧i el kitabı (11.baskı). Ankara: Pegem Akademi Yayincilik.

Büyüköztürk, Ş., Akgün, Ö.E., Özkahveci, Ö., \& Demirel, F. (2004). The validity and reliability study of the turkish version of the Motivated Strategies for Learning Questionnaire. Educational Sciences: Theory \& Practice, 4(2), 231-239.

Byrne, B. M., \& Campbell, T. L. (1999). Cross-cultural comparisons and the presumption of equivalent measurement and theoretical structure: A look beneath the surface. Journal of Cross-Cultural Psychology, 30(4), 555-574.

Cronbach, L. J. (1951). Coefficient alpha and the internal structure of tests. Psychometrika, 16(3), 297-334.

Delve, C. L., Mintz, S. D., \& Stewart, G. M. (1990). Promoting values development through community service: A design. New Directions for Student Services, 4, 7-29.

Deniz, K. Z. (2007). Psikolojik ölçme aracı uyarlama. Ankara Üniversitesi Eğitim Bilimleri Fakültesi Dergisi, 40(1), 1-16.

Dinçer, C.., Ergül, A., Şen, M., \& Çabuk, B. (2011). Bir topluma hizmet uygulaması örneği: "Haydi kavram oyuncaklarıyla oynayalım". Kastamonu Ë̈itim Dergisi, 19(1), 19-38.

Elma, C., Kesten, A., Kıroğlu, K., Mercan Uzun, E., Dicle, A. N., \& Palavan, Ö. (2010). Öğretmen adaylarının topluma hizmet uygulamaları dersine ilişkin alg1ları. Kuram ve Uygulamada Eğitim Yönetimi, 16(2), 231-252.

Field, A. (2009). Discovering statistics using SPSS (3rd ed.). London: Sage Publications Ltd.

Gefen, D., \& Straub, D. W. (2000). The relative importance of perceived ease of use in IS adoption: A study of e-commerce adoption. Journal of the Association for Information Systems, 1(1), 1-28.

Gökçe, N. (2011). Sosyal bilgiler öğretmen adaylarının topluma hizmet uygulamalarına ilişkin değerlendirmeleri. Uluslararası İnsan Bilimleri Dergisi, 8(2), 176-194.

Gözüm S., \& Aksayan S. (2003). Kültürlerarası ölçek uyarlaması için rehber II: Psikometrik özellikler ve kültürlerarası karşılaşturma. Hemșirelikte Araștırma-Geliștirme, 5(1), 3-14.

Gorsuch, R. L. (1974). Factor analysis. Philadelphia: W. B. Saunders Company.

Hair, J. F. Jr., Black, W. C., Babin, B.J., \& Anderson, R.E. (2010). Multivariate data analysis (7th ed.). New Jersey: Pearson Prentice Hall.

Hooper, D., Coughlan, J., \& Mullen, M. R. (2008). Structural equation modelling: Guidelines for determining model fit. Journal of Business Research Methods, 6, 53-60.

Horzum, M. B., \& Bektaş, M. (2012). Otantik öğrenmenin topluma hizmet uygulamaları dersini alan öğretmen adaylarının derse yönelik tutum ve memnuniyetine etkisi. Kastamonu Eğitim Dergisi, 20(1), 341-361.

Hu, L., \& Bentler, P. M. (1999). Cutoff criteria for fit indexes in covariance structure analysis: Conventional criteria versus new alternatives. Structural Equation Modeling, 6(1), 1-55.

Kaiser, H. F. (1974). An index of factorial simplicity. Psychometrika, 39(1), 31-36.

Kesten, A., Elma, C., Kıroğlu, K., Dicle, A. N., Mercan Uzun, E., \& Palavan, Ö. (2011). Kurum yöneticilerinin bakış açısıyla topluma hizmet uygulamaları. Electronic Journal of Social Sciences, 10(35), 45-63.

Kline, P. (2000). An easy guide to factor analysis. New York: Routledge.

Küçükoğlu, A. (2011). Opinions of pre-service teachers towards community service-learning experiences. Perspectives in Education, 29(2), 80-89.

Küçükoğlu, A., Kaya, H. İ., \& Bay, E. (2010, Mayı). Hiæmet ederek ögrenme: Öğretmen eğitiminde yeni bir yaklaşım. II. Uluslararası Öğretmen Yetiştirme Politikaları ve Sorunları Sempozyumu, Hacettepe Üniversitesi Ĕgitim Fakültesi, Ankara.

Küçükoğlu, A., Kaya, H. İ., Bay, E., Taşg1n, A., \& Ozan, C. (2010, Mayıs). Community service-learning: An approach supporting entrepreneurship democratic participation in teacher education. The Second International Congress of Educational Research, Antalya, 1039-1059. 
Küçükoğlu, A., \& Ozan, C. (2015). The short version of service-learning involvement scale: The study of linguistic equivalence, validity and reliability. International Journal of Human Sciences, 12(1), 790-810. doi: $10.14687 /$ ijhs.v12i1.2852

Küçükoğlu, A., Ozan, C., \& Taşgın, A. (2012, Eylül). Topluma bizmet uygulamalar dersinde yansiticı günlükler. 2. Ulusal Eğitim Programları ve Öğretim Kongresi, Abant İzzet Baysal Üniversitesi, Bolu.

Nunnally, J., \& Bernstein, I. (1994). Psychometric theory. New York: McGraw-Hill.

Olney, C., \& Grande, S. (1995). Validation of a scale to measure development of social responsibility. Michigan Journal of Community Service Learning, 2, 43-53.

Özdemir, S., M., \& Tokcan H. (2010). Topluma hizmet uygulamaları dersinin öğretmen adaylarının görüsslerine göre değerlendirilmesi. Selçuk Üniversitesi Abmet Kelesoğlu Eğitim Fakülltesi Dergisi, 30, 41-61.

Özgüven, İ. E. (2000). Psikolojik testler. Ankara: Pdrem Yayınları.

Pallant, J. (2005). SPSS survival manual: A step by step guide to data analysis using SPSS for Windows version 12 (2nd ed.). Crows Nest NSW, Australia: Allen \& Unwin.

Saran, M., Coşkun, G., İnal-Zorel, F., \& Aksoy, Z. (2011). Üniversitelerde sosyal sorumluluk bilincinin geliştirilmesi: Ege Üniversitesi topluma hizmet uygulamaları dersi üzerine bir arașturma. Journal of Yasar University, 22(6), 3732-3747.

Sönmez, Ö. F. (2010). Sosyal bilgiler öğretmen adaylarının topluma hizmet uygulamaları dersine yönelik görüsslerinin kazanım boyutunda değerlendirilmesi. The Black Sea Journal of Social Sciences, 2(2), 53-71.

Sümer, N. (2000). Yapısal eşitlik modelleri: Temel kavramlar ve örnek uygulamalar. Türk Psikoloji Yarzlar, 3(6), 49-74.

Tabachnick, B. G., \& Fidell, L. S. (2007). Using multivariate statistics (5th ed.). Boston: Pearson Education Inc.

Tavsanc1l, E. (2002). Tutumlarn ölçülmesi ve SPSS Ye veri analiz̨i. Ankara: Nobel Yayınc1lik.

Uğurlu, Z., \& Kıral, E. (2011, Nisan). Öğretmen adaylarmm topluma bizmet uygulamalar dersinin işleyis süreci ve kazanmlarma iliskin görüsleri. 2. International Conference on $\mathrm{New}$ Trends in Education and Their Implications, Antalya, 720-734.

Ural-Keleş, P., \& Aydın, S. (2011). Fen bilgisi öğretmen adaylarının topluma hizmet uygulamaları dersi hakkındaki görüşlerinin belirlenmesi. Eræ̌incan Üniversitesi Fen Bilimleri Enstitïsü Dergisi, 4(2), 169-184.

Yılmaz, K. (2011). Eğitim fakültelerinin sosyal sorumluluğu ve topluma hizmet uygulamaları dersi: Nitel bir araşturma. Kuramsal Ë̆itimbilim, 4(2), 86-108. 
Küçükoğlu, A., \& Ozan, C. (2015). The short version of service-learning involvement scale: The study of linguistic equivalence, validity and reliability. International Journal of Human Sciences, 12(1), 790-810. doi: $10.14687 /$ ijhs.v12i1.2852

\section{Appendix 1.}

\section{Scale of Service Learning (Hizmet Ederek Öğrenme Ölçeği)}

\section{Original Version Turkish Version}

I would be involved in my volunteer

1 activities whether or not I had friends working with me.

I choose my volunteer work based on

2 what members of my peer group decide to do.

3 I am starting to realize how much I can learn through my volunteer work.

Helping to raise money for charitable

4 organizations is just as important as working more directly and consistently with a charitable organization.

I have been amazed at what I can learn

5 from people I consider to be "underprivileged".

I doubt that my volunteer work will ever have much effect on my career goals.

My volunteer work has made me more

7 aware of how unfair life can be to some people.

My participation in my volunteer

8 activities has caused me to change how I treat other people.

There are so many places and causes that

9 need volunteer help that I sometimes feel confused about where I should help.

I prefer to work with local agencies, so

10 my efforts benefit people from my community.

11 I realize that the causes of most social issues are very complex.

I believe it takes more than time, money,

12 and community efforts to change social problems; we also need to work for change at a national or global level.

I doubt that I would have done my last

13 volunteer activity if my peer group had not taken it on as a service project.
Birlikte çalıştı̆̆ım arkadaşlarım olsa da olmasa da gönüllü faaliyetlerde yer alırım.

Proje çalısmamı yaparken, grup üyelerinin aldıkları karara uyarım.

Gönüllü çalışmalarım sayesinde ne kadar öğrenebileceğimin farkına varmaya başladım.

Hayır kurumları için maddi yardımlarda bulunmak, o kurum için doğrudan ve sürekli olarak çalıșmak kadar önemlidir.

"Yoksun" olarak düşündüğüm insanlardan öğrenebileceğim şeylere hayret ettim.

Katıldığım topluma hizmet çalısmalarının kariyerim üzerinde çok fazla etkisi olacağından emin değilim.

Gönüllü çalışmam, hayatın bazı insanlar için ne kadar adaletsiz olabileceğini daha iyi anlamamı sağladi.

Topluma hizmet faaliyetleri insanlara karşı davranışlarımı olumlu yönde etkiledi.

Yardıma ihtiyaç duyan o kadar yer ve durum var ki, nereye yardım etmem gerektiğini şaşırıyorum.

Topluma hizmet uygulamalarında yerel kurumları tercih etmemin nedeni çalş̧malarımdan çevremdeki insanların yararlanmasını sağlamaktır.

Çoğu sosyal konunun nedenlerinin çok karmaşık olduğunun farkındayım.

Sosyal problemleri çözmek için daha fazla zaman, para ve toplumsal çaba gerektiğine inanıyorum; ulusal veya küresel düzeyde değişim için de çalışmamız gerekiyor.

Hizmet projeleri, topluma hizmet uygulamalar1 dersi için bir zorunluluk olmasayd,, bu tür faaliyetlere katılmazdım. 
Küçükoğlu, A., \& Ozan, C. (2015). The short version of service-learning involvement scale: The study of linguistic equivalence, validity and reliability. International Journal of Human Sciences, 12(1), 790-810. doi: $10.14687 /$ ijhs.v12i1.2852

I would not change my volunteer

14 activities even if my parents or friends disapproved.

I often examine my motives for being

15 involved with certain social issues to be sure I am not involved for selfish reasons.

My main responsibility toward disadvantaged people is to provide help through regular contributions of my time and efforts.

17 I think about social justice and how I can make a difference.

18 I choose my volunteer work based on an issue about which I feel very strongly.

19 I can learn from the people who benefit from my volunteer efforts.

While I enjoy having positive relationships with other volunteers who

20 are working for the same issue as I am, I would still pursue this volunteer activity even if I had to do it alone.

21 I sometimes feel overwhelmed by how frustrating volunteer work can be.

I would be more likely to participate in a

22 volunteer activity if it didn't require more than a few hours of my time.

\section{I participate in service projects because I} understand how important the service is to those needing it.

24 I believe that I will be involved in social justice issues for the rest of my life.

Ailem ya da arkadaşlarım onaylamasa bile gönüllü faaliyetlere katılmaktan vazgeçmem.

Topluma hizmet çalışmalarında yer almamda kişisel faktörlerimin ne derece etkili olduğunu sık sik sorgularım.

Yardıma ihtiyaç duyan insanlara karşı en temel sorumluluğum, topluma hizmet çalışmalarına düzenli olarak katılarak onlara yardımcı olmaktır.

Sosyal adalet konusunda nasıl bir farklilık yaratabileceğimi düşünürüm.

Gönüllü çalışmamı en başarılı olabileceğim bir konu hakkında seçerim.

Topluma hizmet çalışmalarından yararlanan kişilerden bir şeyler öğrendim.

Topluma hizmet faaliyetlerini birlikte çalışmaktan zevk aldığım grup arkadaşlarım olmaksızın, tek başıma yürütmek zorunda kalsam dahi, bu faaliyetlere katılmak isterim.

Topluma hizmet çalışmalarımın zaman zaman hayal kırıklığıyla sonuçlanması beni hayrete düşürüyor.

Çok fazla zamanımı almasa, topluma hizmet çalışmalarına daha fazla katılırım.

Mağdur insanların topluma hizmet çalışmalarına ne kadar ihtiyaç duyduğunu bildiğim için bu çalışmalara katılırım.

Bundan sonra, sosyal adalet konularına yönelik çalışmalarda yer almak istiyorum.

I usually feel overwhelmed at the

25 complexity of social problems like homelessness and hunger.

I feel I am more committed to a social

26 issue than to a social or community agency.

If I missed a volunteer activity, I would

27 feel bad primarily because I had let my peer group down.
Zaman zaman sosyal sorunların karmaşıklığından bunaliyorum.

Sosyal sorunları, bu sorunlarla ilgilenen kurumlardan daha fazla önemsediğimi düşünüyorum.

Öncelikle, birlikte çalıştığım arkadaşlarımı hayal kırıklı̆̆ına uğratacağımı düşündüğüm için, topluma hizmet çalışmalarını aksatmak istemiyorum. 
Küçükoğlu, A., \& Ozan, C. (2015). The short version of service-learning involvement scale: The study of linguistic equivalence, validity and reliability. International Journal of Human Sciences, 12(1), 790-810. doi: $10.14687 /$ ijhs.v12i1.2852

I do as much volunteer work as I do

28 because I am committed to fighting social injustice.
Sosyal adaletsizlikle mücadelede kararlı olduğum için, çok sayıda gönüllü çalışmaya katılırım.

I think that people like me who are more

29 fortunate in life need to help less

İmkânı olan insanların, ihtiyacı olan insanlara fortunate people with their needs and yardım etmesi gerektiğini düşünüyorum. problems.

While my volunteer work can be frustrating at times, I seldom feel overwhelmed by that frustration anymore.

Topluma hizmet çalişmalarım zaman zaman beni hayal kırıkliğına uğratsa da, bu durum beni fazla rahatsiz etmez. 